\title{
Mechanical Stresses and Crack Analysis of Concrete under the Hygrothermic Effect
}

\section{Dahmani}

Mouloud Mammeri University, Tizi-Ouzou, Algeria

lahlou_d@yahoo.fr

УДК 539.4

\section{Анализ механических напряжений и роста трещины в бетоне с учетом гигротермического эффекта}

\section{Л. Дахмани}

Университет им. Мулуда Маммери, Тизи-Узу, Алжир

Пористость и абсорбционная способность бетона могут изменяться вследствие гигротермических процессов, что приведет к инициированию и росту трещии, нарушающих сплошность бетонных конструкиий. Разработана конечноэлементная методика моделирования инициирования и роста трещин с учетом изменения влажности и теплопроводности бетона. Описана оригинальная концепиия, основанная на трехмерном напряженном состоянии узлов интегрирования в каждом конечном элементе. Для оценки растрескивания бетонной конструкиии предложено использовать глобальную относительную плотность трещины, которая может быть индикатором общего уровня ухудшения параметров состояния конструкиии.

Ключевые слова: бетон, теплоперенос, изменение влажности, растрескивание.

Introduction. Various environmental loadings, such as variation in the ambient temperature, fluctuation of the relative humidity, the exposure to chemically harmful substances, etc., cause the progressive deterioration of the concrete structures. The long-term durability of concrete is largely governed by the resistance of concrete to various physical and chemical processes of deterioration. The interactions between these processes of deterioration become increasingly necessary to be considered in the evaluation of durability.

With the fast development of data processing, the digital simulation found an application increasingly extended by modeling various processes of deterioration [1-3].

However, all these digital models are specific programs describing only the processes considered, which limits their application to a broad variety of applications. Moreover, the analysis of the mechanical stresses induced by the deterioration process did not become available, which makes it impossible to evaluate the influence of acceleration of cracks on the deterioration of concrete and to predict the lifespan of the concrete structure after cracking. 
This study overcomes the above limitations by developing a finite element model by using commercial software ANSYS [4, 5], where the processes of thermal transfer and moisture transport are modelled.

Modeling of the Phenomenon. Before carrying out the hygrothermic simulation of the concrete structures, it is necessary to discuss the digital models of each process of deterioration. Based on the simulation of each process of deterioration and consideration of various couplings between them, the method of digital simulation of the coupled processes of deterioration is then developed.

Thermal Transfer. Based on the principle of energy conservation [3], the process of thermal transfer is governed by the Fourier law as follows:

$$
\operatorname{div}[k, \operatorname{grad}(T)]+Q^{\prime}(T)=\rho c \frac{\partial T}{\partial t},
$$

where $K$ is the thermal conductivity of concrete $\left[\mathrm{W} /\left(\mathrm{m} \cdot{ }^{\circ} \mathrm{C}\right)\right], T$ is the temperature of concrete $\left({ }^{\circ} \mathrm{C}\right), \rho$ is the density of concrete $\left(\mathrm{kg} / \mathrm{m}^{3}\right), C$ is the specific heat capacity of concrete $\left[\mathrm{J} /\left(\mathrm{kg} \cdot{ }^{\circ} \mathrm{C}\right)\right]$, and $Q^{\prime}$ is the heat generation rate of concrete $\left[\mathrm{J} /\left(\mathrm{m}^{3} \cdot \mathrm{s}\right)\right]$.

Assuming that no heat generation rate exists in the hardened concrete, the term $Q^{\prime}$ can be neglected.

The thermal conductivity, density, and specific heat capacity of concrete may be assumed to be constant. In this case, the governing differential equation of heat transfer may be solved as a linear problem with no effect of moisture transport process.

The relation between the temperature variation and the associated mechanical strain (thermal strain) can be expressed as follows:

$$
\varepsilon_{\text {thermal }}=\alpha \Delta T
$$

where $\varepsilon_{\text {thermal }}$ is the thermal deformation, $\alpha$ is the thermal coefficient of expansion $\left({ }^{\circ} \mathrm{C}^{-1}\right)$, and $\Delta T$ is the thermal gradient $\left({ }^{\circ} \mathrm{C}\right)$. The simulation of the thermal transfer and the associated thermal stresses can be carried out by using the transient thermal stress analysis, which is available in the finite element commercial code ANSYS.

Moisture Transport. The process of moisture transport which is described by the Fick law [6] is based on the second principle of conservation of mass and is given as follows:

$$
\operatorname{div}\left[D_{m} \operatorname{grad}(W)\right]+Q_{m}^{\prime}(t)=\frac{\partial W}{\partial t},
$$

where $D_{m}$ is diffusion coefficient of moisture $\left(\mathrm{m}^{2} / \mathrm{s}\right), W$ is free water content in concrete $\left(\mathrm{m}^{3} / \mathrm{m}^{3}\right)$, and $Q_{m}^{\prime}$ is the source of moisture of concrete $\left[\mathrm{m}^{3} /\left(\mathrm{m}^{3} \cdot \mathrm{s}\right)\right]$.

The amount of water content consumed by hydration reaction is assumed to be very small and therefore ignored. 
Numerical simulation of moisture transport is essentially a nonlinear problem, since the moisture diffusivity $D_{m}$ is dependent on pore relative humidity, temperature, etc.

The relationship between moisture content variation and the associated mechanical strain (i.e., wetting expansion/drying shrinkage strain) can be expressed as

$$
\varepsilon_{\text {shrinkage }}=\beta\left(W-W_{0}\right),
$$

where $\varepsilon_{\text {shrinkage }}$ is the shrinkage strain, $\beta$ is hydral contraction coefficient of concrete $\left(\mathrm{m}^{3} / \mathrm{m}^{3}\right)$, and $W_{0}$ is the initial free moisture content of concrete $\left(\mathrm{m}^{3} / \mathrm{m}^{3}\right)$.

The governing differential equations of heat transfer and moisture transport are similar, therefore it is possible to simulate the moisture transport process and the associated drying stress in concrete using the transient thermal stress analysis mentioned above. The physical parameters of the heat transfer process correspond to those in the moisture transport process: for the main field variable, the temperature maps to the free moisture content; for the transport property, the thermal conductivity maps to the diffusivity of moisture; for the associated mechanical stress, the thermal expansion coefficient maps to the hydral contraction coefficient.

Simulation Procedure. The heat transfer and moisture transport processes are defined as individual physical environments first. The physical environment functions like an independent module, where all related finite element types, material properties, geometric model, boundary conditions and loads, as well as meshing of the solid model for the specific physical field (such as temperature field, moisture content field, and stress field) are defined accordingly. Next, a sequentially coupled multiphysical analysis method is utilized to recall each physical environment in turn and to perform the simulation of each deterioration process iteratively within each time step. To account for the potential couplings between various deterioration processes, the output result of one degradation process may be used to modify the transport properties to the other degradation process. The flowchart of the simulation procedure for the coupled degradation processes is summarized in Fig. 1.

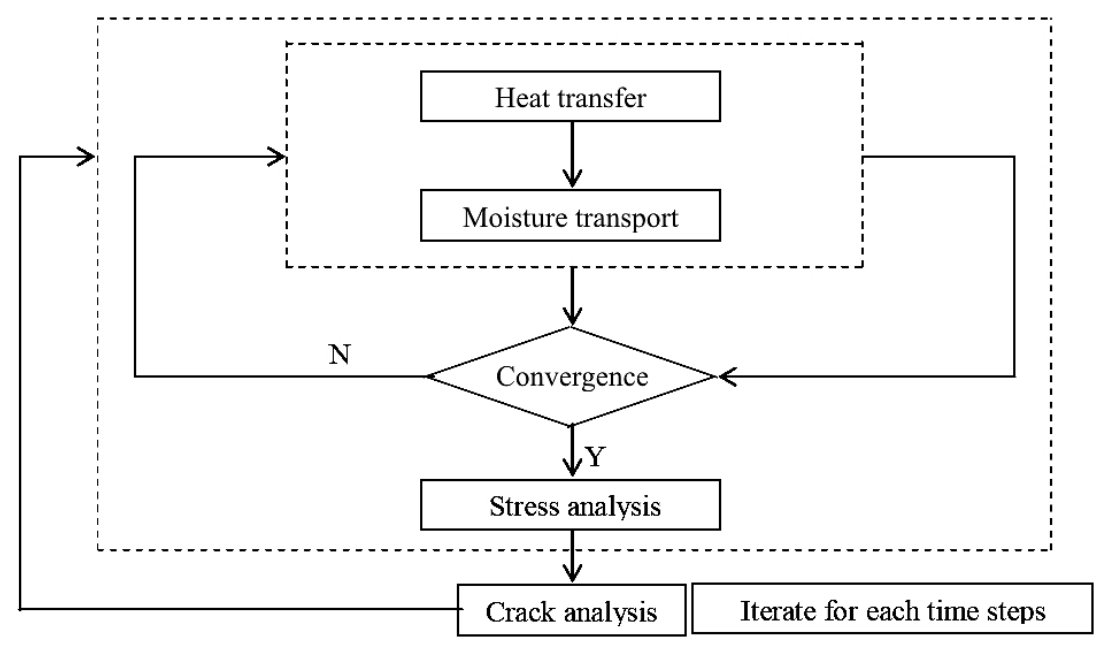

Fig. 1. Coupled field simulation procedure. 
A self-programmed code in ANSYS Parametric Design Language (APDL) is required to implement the flowchart and the proposed computational methodology.

The coupled-field analysis is performed in the following manner.

At each time step, perform the transient heat transfer analysis first to obtain the spatial temperature distribution, where the nodal temperature is stored in array A. Moisture transport analysis is performed to determine the spatial distribution of moisture content, where the nodal moisture content is stored in array B. Finally, stress analysis and associated cracking analysis are performed to obtain the spatial distribution of the resultant stress, where the nodal stresses are stored in array $\mathrm{C}$.

Cracking Analysis of Concrete. Most deterioration processes are able to alter the porosity and permeability of concrete, trigger the initiation and growth of cracks, and thus impair the integrity of the concrete structure.

Ngo and Scordelis [7] introduced the effect of cracking into the finite element analysis of reinforced concrete structures. Since then, numerous researchers (Alfaiate et al. [8], de Borst [9], Loo and Guan [10]) have made substantive contributions in this field. There usually exist two finite element-based approaches to simulate the concrete cracking - discrete cracking approach and smeared cracking approach.

Discrete Cracking Approach. Discrete cracks are treated directly as geometric discontinuities, where the intact portion of concrete is generally assumed to behave elastically, while the crack propagation is modelled by changing the topology of the finite element model. Adaptive remeshing is required to implement the simulation. It is extremely difficult to implement the simulation of concrete cracking caused by the multiple coupled deterioration processes using the discrete cracking approach.

Smeared Cracking Approach. Smeared cracks are assumed to be spatially distributed over the entire volume represented by a local finite element or only by the volume attached to one integration point within the finite element. The stiffness matrix of each concrete element is modified accordingly to accommodate the mechanical deterioration due to cracking without changing the topology of finite element model. This approach proves to be efficient when incorporated in finite element analysis.

Commercial finite element software ANSYS is adopted herein to simulate the mechanical response of concrete subjected to coupled hydrothermal process, where the uniaxial constitutive model of concrete shown in Fig. 2 is adopted.

An 8-node 3D thermal element SOLID70 with one temperature DOF at each node is selected for the simulation of heat transfer and moisture transport processes. For subsequent mechanical stress analysis, a corresponding 8-node 3D concrete element SOLID65 with three translation DOFs at each node is selected.

This concrete element has eight nodes with three DOFs at each node translations in the nodal $x, y$, and $z$ directions, and eight integration points inside. Based on specified constitutive model and failure criterion, the concrete element allows smeared reinforcement, plastic deformation, cracking in tension in three orthogonal directions, shear transfer capacity, and crushing in compression. The geometry and node locations for the concrete element are shown in Fig. 3. 


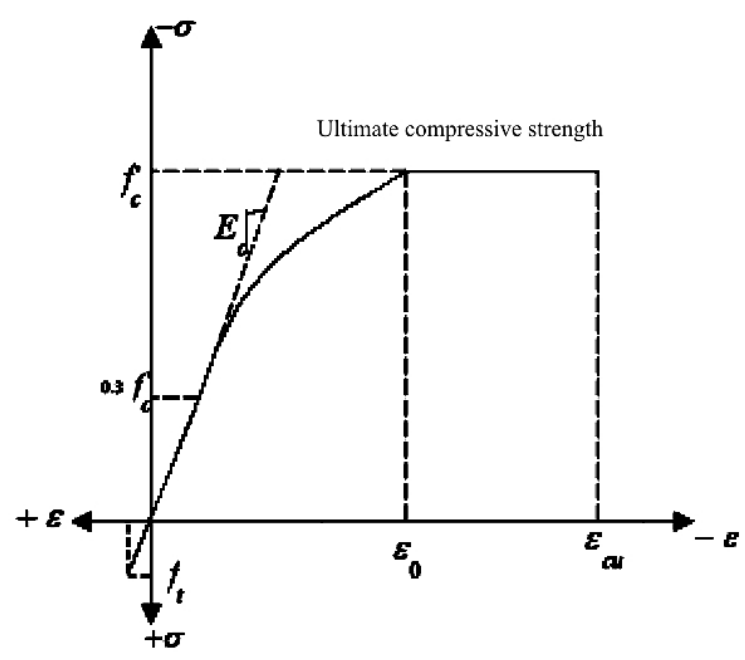

Fig. 2. Uniaxial constitutive model.
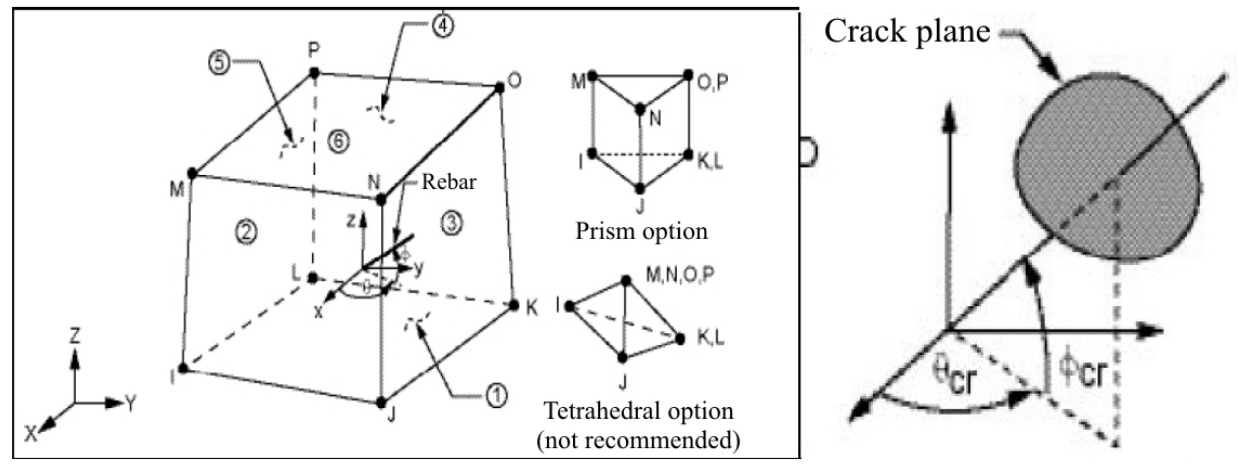

Fig. 3. SOLID65 concrete element.

The William and Warnke failure criterion [11] under multiaxial stress state is adopted to assess the initiation of failure and identify the corresponding failure modes (including cracking and crushing) at the centroid of a concrete element or one of its integration points. The criterion is expressed uniformly as

$$
\frac{F}{f_{c}^{\prime}}-S \geq 0
$$

where $F$ is a function of the principal stresses, $S$ is the spatial failure surface expressed in terms of the principal stresses and the material properties of concrete, and $f_{c}^{\prime}$ is the maximal compressive strength of concrete. Only if Eq. (5) is satisfied, the failure of concrete element or that of its integration points assumed to occur $[4,5]$.

Figure 4 represents the projection of 3D failure surface $S$ in biaxial or nearly biaxial stress states.

The above failure surface in Fig. 4 can be divided into four domains according to different failure modes as: 


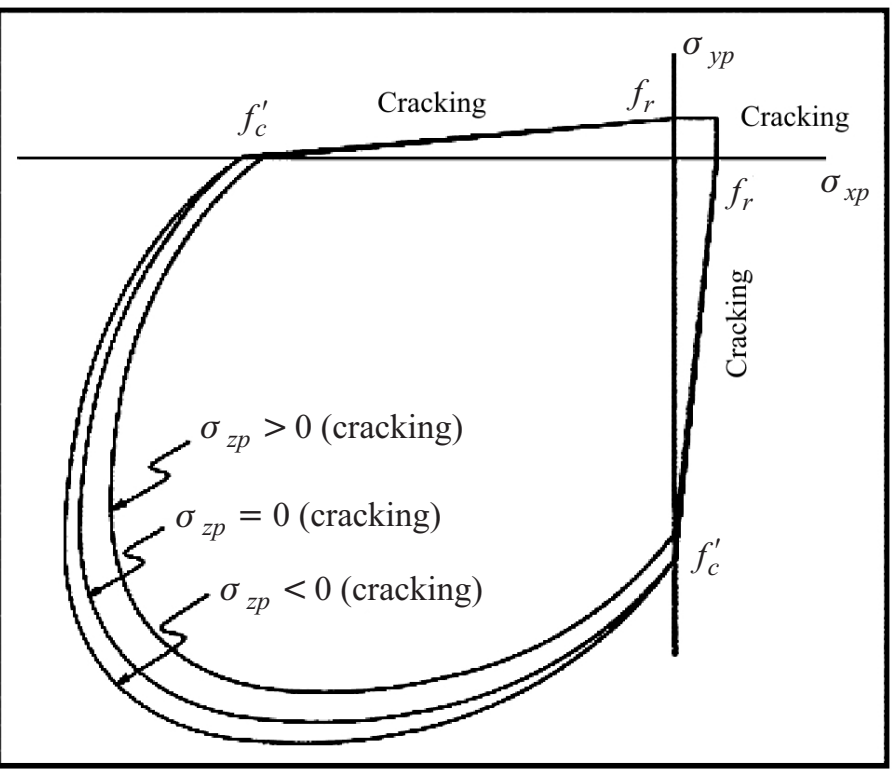

Fig. 4. Failure surface projection for concrete $[4,5]$.

1. $0 \geq \sigma_{1} \geq \sigma_{2} \geq \sigma_{3}$ (compression-compression-compression). Concrete is assumed to be crushed provided Eq. (5) is satisfied.

2. $\sigma_{1} \geq 0 \geq \sigma_{2} \geq \sigma_{3}$ (tension-compression-compression).

If Eq. (5) is satisfied, cracking will occur in a direction perpendicular to $\sigma_{1}$.

3. $\sigma_{1} \geq \sigma_{2} \geq 0 \geq \sigma_{3}$ (tension-tension-compression).

If Eq. (5) is satisfied, the ultimate tensile strength linearly decreases with the drop of $\sigma_{3}$. Meanwhile, cracking occurs in the planes perpendicular to principal stresses $\sigma_{1}$ or $\sigma_{2}$ separately.

4. $\sigma_{1} \geq \sigma_{2} \geq \sigma_{3} \geq 0$ (tension-tension-tension).

If Eq. (5) is satisfied, the ultimate tensile strength attains $f_{t}$. Meanwhile, cracking occurs in the planes perpendicular to principal stresses $\sigma_{1}, \sigma_{2}$, or $\sigma_{3}$.

In all above four cases, $\sigma_{1}=\max \left(\sigma_{x p}, \sigma_{y p}, \sigma_{z p}\right)$ is the first principal stress, and $\sigma_{3}=\min \left(\sigma_{x p}, \sigma_{y p}, \sigma_{z p}\right)$ is the third principal stress. Both the function $F$ and the failure surface $S$ take different forms to accommodate corresponding failure modes. As any failure mode occurs, the stiffness matrix of the concrete element is modified accordingly to consider the crack-induced mechanical degradation.

The number of cracks per unit volume of concrete is usually defined as the crack density. This concept may be modified to take advantage of the output of smeared cracking analysis - the number, location, and state of cracked integration points in one concrete element or those of cracked elements in the entire concrete structure. In this paper, the global relative crack density (GRCD) is proposed to evaluate the cracking state of the entire concrete structure. GRCD is able to quantify the overall cracking state of the concrete structure and serve as an appropriate failure index. Once GRCD exceeds a specified threshold value based on practical engineering requirements, the service life of the concrete structure can be assumed to end. 
GRCD is defined as

$$
\rho_{\text {global }}=\frac{N_{\text {crack }}}{N_{\text {total }}},
$$

where $0 \leq \rho_{\text {global }} \leq 1.0, \quad N_{\text {total }}$ is the total number of concrete elements, and $N_{\text {crack }}$ is the number of cracked concrete elements.

Numerical Example. A plain concrete block $1.0 \mathrm{~m}$ long, $1.0 \mathrm{~m}$ wide, and $0.5 \mathrm{~m}$ thick is selected herein to illustrate the simulation procedure of crack propagation for concrete exposed to the coupled hygrothermal processes.

The total time length is assumed to be one year, which is divided into nine time steps with an average of 40 substeps for each time step. The average duration of each substep (i.e., about one day) is small enough to guarantee a stable solution. To facilitate the finite element analysis, the unit of time is maintained consistently in days, thus the transport properties of all deterioration processes are adjusted accordingly. The finite element model is shown in Fig. 5.

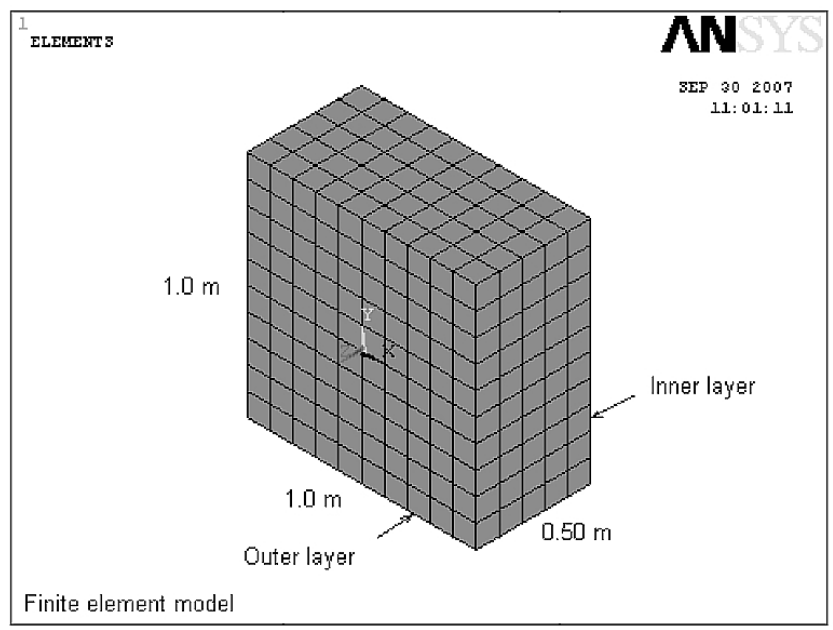

Fig. 5. Finite element model.

The temperature of $-10^{\circ} \mathrm{C}$ and relative humidity of $80 \%$ are enforced on the outer layer of the plain concrete block. On the inner layer, a temperature of $20^{\circ} \mathrm{C}$ and a relative humidity of $10 \%$ are applied. The initial temperature of the entire concrete block is assumed to be $20^{\circ} \mathrm{C}$. Meanwhile, the four side surfaces of the concrete block are assumed to be isolated from any heat/moisture flux. In addition, structural displacements in all three orthogonal directions are restrained at the four side surfaces as structural boundary conditions.

Like macroscopic model, the simulation method does not require data concerning the composition of concrete. Alternatively, it employs only the macroscopic properties of material enumerated in Table 1.

Results and Discussion. The cracking state of the entire concrete block at each time step is illustrated in Fig. 6, where the right side view of the plain concrete block in Fig. 5 is shown. It can be observed that more and more dense microcracks uniformly distributed over the entire concrete volume propagate with time. 
$\mathrm{T}$ a b 1 e 1

Material Properties of Concrete [12]

\begin{tabular}{||l|c||}
\hline \multicolumn{1}{|c|}{ Material properties } & Values adopted \\
\hline Compressive strength & $f_{c}^{\prime}=30 \mathrm{MPa}$ \\
\hline Tensile strength & $f_{t}=3 \mathrm{MPa}$ \\
\hline Strain at peak stress & $\varepsilon_{0}=0.002$ \\
\hline Ultimate strain & $\varepsilon_{c u}=0.003$ \\
\hline Elastic modulus & $E_{c}=30 \mathrm{GPa}$ \\
\hline Poisson's ratio & $v=0.2$ \\
\hline Density & $\rho=2400 \mathrm{~kg} / \mathrm{m}^{3}$ \\
\hline Thermal conductivity & $k=2 \mathrm{~W} /\left(\mathrm{m} \cdot{ }^{\circ} \mathrm{C}\right)$ \\
\hline Specific heat capacity & $c=1000 \mathrm{~J} /\left(\mathrm{kg} \cdot{ }^{\circ} \mathrm{C}\right)$ \\
\hline Thermal expansion coefficient & $\alpha=1.0 \cdot 10^{-5}{ }^{\circ} \mathrm{C}{ }^{-1}$ \\
\hline Hydral contraction coefficient & $\beta=9.96 \cdot 10^{-3} \mathrm{~m}^{3} / \mathrm{m}^{3}$ \\
\hline \hline
\end{tabular}

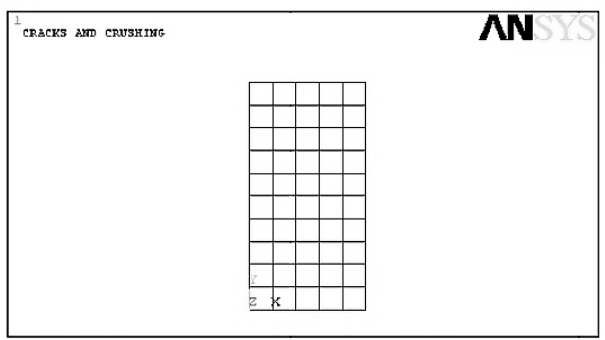

a

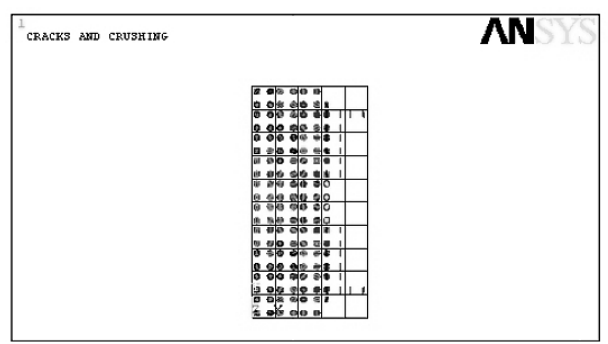

$\mathrm{c}$

\begin{tabular}{|c|c|}
\hline CRACKS AMD CRUSHIMG & 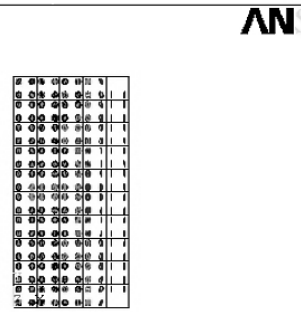 \\
\hline
\end{tabular}

e

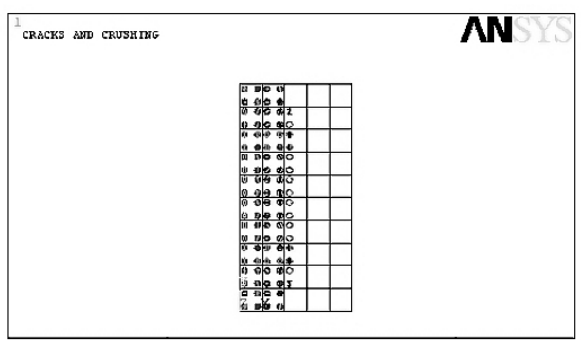

b

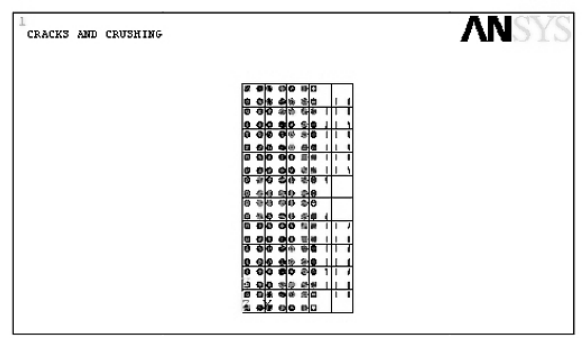

d

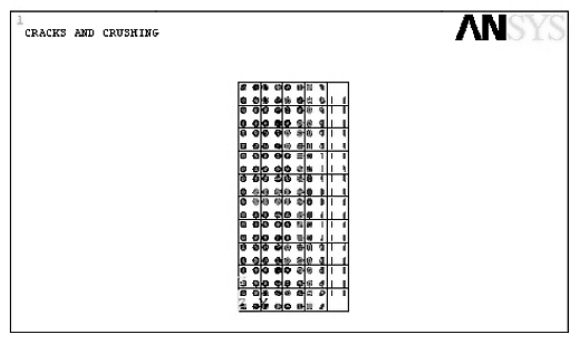

f

Fig. 6. Crack accumulation in the concrete structure: (a) 0.1 year; (b) 0.3 year; (c) 0.5 year; (d) 0.6 year; (e) 0.8 year; (f) 1.0 year. 


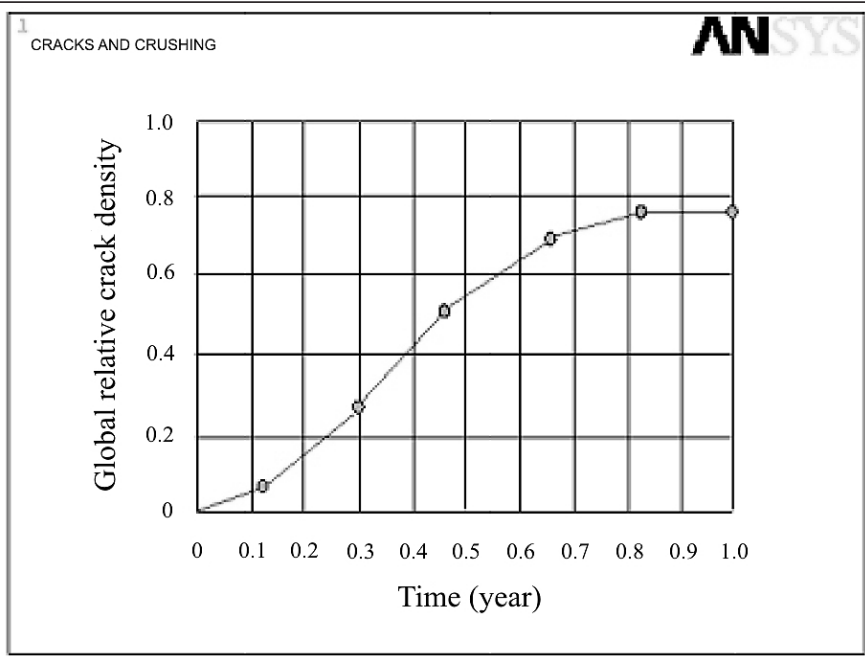

Fig. 7. GRCD of a concrete block.

The corresponding GRCD is shown in Fig. 7, which increases with time and verifies the observation in Fig. 6. It can be observed that about $75 \%$ concrete finite elements are cracked, though each element may attain a different cracking level.

It is observed that the values of GRCD can be divided roughly into three phases. During the first phase ( $0-0.2$ year), almost no cracks occur, and GRCD approaches zero.

During the second phase $(0.2-0.6$ year), a great number of cracks are generated, and GRCD increases quickly. During the third phase (0.6-1.0 year), GRCD gradually approaches its maximum value, which may be explained as follows. The cracking state of the concrete element has reached such an extent that its degraded stiffness does not allow it to carry more loads (the other uncracked or less cracked concrete elements may take the additional load).

Conclusions. An integrated finite element-based computational framework has been proposed in this study to simulate the crack propagation in concrete exposed to coupled degradation processes (heat transfer and moisture transport).

The smeared cracking approach is utilized to simulate the crack propagation.

Finally, the global relative crack density is proposed to describe the cracking state of the entire structure and serve as an appropriate index to evaluate the overall deterioration level of the structure. This methodology establishes a reasonable basis for quantitative long-term durability assessment of concrete structures under coupled deterioration processes.

Further work can extend this methodology to consider more deterioration processes, including carbonation process, chloride penetration process, reinforcement corrosion and rust expansion process.

\section{Резгме}

Шпаристість і абсорбційна здатність бетону можуть змінюватися внаслідок гігротермічних процесів, що призведе до ініціювання і росту тріщин, які зумовлюють порушення суцільності бетонних конструкцій. Розроблено скін- 
ченноелементну методику моделювання ініціювання і росту тріщин з урахуванням зміни вологості й теплопровідності бетону. Описано оригінальну концепцію, що базується на тривимірному напруженому стані вузлів інтегрування у кожному скінченному елементі. Для оцінки розтріскування бетонної конструкції запропоновано використовувати глобальну відносну щільність тріщини, яка може бути індикатором загального рівня погіршення параметрів стану конструкції.

1. L. Basheer, J. Kropp, and D. J. Cleland, "Assessment of the durability of concrete from its permeation properties: a review," Constr. Build. Mater., 15, No. 2, 93-103 (2001).

2. T. Ishida and K. Maekawa, "Modeling of $\mathrm{pH}$ profile in pore water based on mass transport and chemical equilibrium theory," in: Proc. of JSCE, No. 648/ V-47 (2000), pp. 125-140.

3. O. B. Isgor and A. G. Razaqpur, "Finite element modeling of coupled heat transfer, moisture transport and carbonation processes in concrete structure," J. Cement Concrete Compos., 26, No. 1, 57-73 (2004).

4. ANSYS Theory Reference: Analysis Tools, 001099, 9th edition, SAS IP, Inc.

5. ANSYS 8.0. The General Purpose of Finite Element Software. Documentation.

6. C. M. Aldea, S. P. Shah, and A. Karr, "Permeability of cracked concrete," Mater. Struct., 32, No. 219, 370-376 (1999).

7. D. Ngo and A. C. and Scordelis, "Finite element analysis of reinforcedconcrete beams," J. Amer. Concrete Inst., 65, No. 9, 757-766 (1967).

8. J. Alfaiate, E. B. Pires, and J. A. C. Martins, "A finite element analysis of non-prescribed crack propagation in concrete," Comput. Struct., 63, No. 1, 17-26 (1997).

9. R. de Borst, "Some recent developments in computational modeling of concrete fracture," Int. J. Fracture, 86, No. 1-2, 5-36 (1997).

10. Y. C. Loo and H. Guan, "Cracking and punching shear failure analysis of RC flat plates," ASCE J. Struct. Eng., 123, No. 10, 1321-1330 (1997).

11. K. J. William and E. P. Warnke, "Constitutive model for the triaxial behavior of concrete," in: Proc. of the International Association for Bridge and Structural Engineering, ISMES, Bergamo, Italy (1975), Vol. 19, p. 174.

12. A. V. Saetta, B. A. Schrefler, and R. V. Vitaliani, "2D model for carbonation and moisture/heat flow in porous materials," Cement Concrete Res., 25, No. 8, 1703-1712 (1995). 